\title{
KEDUDUKAN KREDITOR SEPARATIS ATAS HAK JAMINAN DALAM PROSES KEPAILITAN
}

\author{
Udin Silalahi*, Claudia \\ Fakultas Hukum Universitas Pelita Harapan \\ Jl. M.H. Thamrin Boulevard 1100 Lippo Village, Tangerang \\ udin.silalahi@uph.edu
}

\begin{abstract}
The position of secured creditor regulated in Article 55 paragraph (1) of Indonesian Bankruptcy Law, Article 21 of the Mortgage Rights Law and Article 27 paragraph (3) of the Fiduciary Security Act that can execute security rights even in the event of bankruptcy, seems to be contrary to the provisions of Article 56 paragraph (1) of Indonesian Bankruptcy Law which suspends the executorial rights and the provisions of Article 56 paragraph (3) in conjunction with Article 59 paragraph (2) which may harm the secured creditor. This research is a normative juridical study with a legal approach and a case approach. The result of this research is that even though the execution right of the secured creditor is suspended, the rights of the secured creditor are still guaranteed by the Indonesian Bankruptcy Law and the transfer of the executorial right from the secured creditor to the curator, then the curator must give the rights of the secured creditor, which is the settlement of the receivables.
\end{abstract}

Keywords: Bankruptcy; Secured Creditor; Security Right

\begin{abstract}
Abstrak
Kedudukan kreditor separatis yang diatur dalam Pasal 55 ayat (1) UUK-PKPU, Pasal 21 UU Hak Tanggungan dan Pasal 27 ayat (3) UU Jaminan Fidusia yang dapat mengeksekusi hak jaminan walaupun terjadi pailit, seolah-olah bertentangan dengan ketentuan Pasal 56 ayat (1) UUKPKPU yang menangguhkan hak eksekutorial tersebut. Adanya ketentuan Pasal 56 ayat (3) jo Pasal 59 ayat (2) dapat merugikan kreditor separatis, karena jika kreditor separatis tidak dapat mengeksekusi hak jaminan kebendaan yang dikuasainya dalam waktu 2 (dua) bulan, maka kurator dapat mengeksekusi dan menggunakan benda tidak bergerak atau menjual harta pailit benda bergerak untuk kelangsungan usaha debitor. Penelitian ini adalah penelitian yuridis normatif dengan pendekatan undang-undang dan pendekatan kasus. Adapun hasil penelitian ini adalah bahwa walapun hak eksekutorial kreditor separatis ditangguhkan, tetapi hak kreditor separatis tetap dijamin oleh UUK-PKPU dan peralihan hak eksekutorial dari kreditor separatis kepada kurator, kurator harus memberikan hak-hak kreditor separatis, yaitu pelunasan piutangnya.
\end{abstract}

Kata Kunci: Kepailitan; Kreditor Separatis; Hak Jaminan

\section{A. Pendahuluan}

Berdasarkan Pasal 1 angka 1 UndangUndang Nomor 37 Tahun 2004 tentang Kepailitan dan Penundaan Kewajiban Pembayaran Utang (UUK-PKPU) "kepailitan adalah sita umum atas semua kekayaan debitor pailit yang pengurusan dan pemberesannya dilakukan oleh kurator di bawah pengawasan hakim pengawas sebagaimana diatur dalam Undang-Undang ini. "Kepailitan adalah pelaksanaan lebih lanjut dari prinsip paritas creditorium dan prinsip pari passu prorata parte dalam 
rezim hukum harta kekayaan (vermogensrechts). (Indonesia, 2004)

Prinsip paritas creditorium berarti bahwa semua kekayaan debitor baik yang berupa barang bergerak ataupun barang tidak bergerak maupun harta yang sekarang telah dipunyai debitor dan barang-barang di kemudian hari akan dimiliki debitor terikat kepada penyelesaian kewajiban debitor. Sedangkan prinsip pari passu prorata parte berarti bahwa harta kekayaan tersebut merupakan jaminan bersama untuk para kreditor dan hasilnya harus dibagikan secara proporsional antara mereka, kecuali apabila antara para kreditor itu ada yang menurut undang-undang harus didahulukan dalam menerima pembayaran tagihannya (Mulyadi, 2001).

Secara umum kreditor dalam hukum dikelompokkan ke dalam beberapa golongan berdasarkan urutan prioritas haknya untuk memperoleh pelunasan piutangnya terhadap para kreditor yang lain (Sjahdeini, 2016). Jenis-jenis kreditor dalam kepailitan terbagi menjadi kreditor separatis, kreditor preferen dan kreditor konkuren (Subhan, 2008). Kreditor separatis adalah kreditor pemegang hak jaminan kebendaan yang dapat bertindak sendiri. Golongan kreditor ini tidak terkena akibat putusan pernyataan pailit, artinya hak-hak eksekusi mereka tetap dapat dijalankan seperti tidak ada kepailitan debitor (Poesoko, 2016) Kreditor preferen yakni kreditor yang memiliki hak istimewa atau hak prioritas. Hak istimewa mengandung makna hak yang oleh undangundang diberikan kepada seorang berpiutang sehingga tingkatannya lebih tinggi daripada orang berpiutang lainnya. Di samping itu juga terdapat kreditor konkuren adalah kreditor bersaing yang tidak mempunyai keistimewaan sehingga kedudukannya sama satu sama lain (Sastrawidjaja, 2014)

Pengaturan mengenai kreditor separatis terdapat dalam Pasal 55 ayat (1) UUKPKPU yang berbunyi:

"Dengan tetap memperhatikan ketentuan sebagaimana dimaksud dalam Pasal 56, Pasal 57, dan Pasal 58, setiap Kreditor pemegang gadai, jaminan fidusia, hak tanggungan, hipotek, atau hak agunan atas kebendaan lainnya, dapat mengeksekusi haknya seolah-olah tidak terjadi kepailitan." (Indonesia, 2004)

Berdasarkan Pasal 55 ayat (1) UUKPKPU, ketika debitor dinyatakan pailit, maka kreditor separatis tetap dapat mengeksekusi haknya seolah-olah tidak terjadi kepailitan. Hal yang demikian juga ditegaskan dalam ketentuan Pasal 21 Undang-Undang Nomor 4 Tahun 1996 tentang Hak Tanggungan Atas Tanah Beserta Benda-Benda yang Berkaitan dengan Tanah (UU Hak Tanggungan) yang menyatakan bahwa: "Apabila pemberi Hak Tanggungan dinyatakan pailit, pemegang Hak Tanggungan tetap berwenang melakukan segala hak yang diperolehnya menurut ketentuan Undang-Undang ini"dan demikian juga dalam Pasal 27 ayat (3) Undang-Undang Nomor 42 Tahun 1999 tentang Jaminan Fidusia (UU Jaminan Fidusia) yang berbunyi bahwa: "Hak yang didahulukan dari Penerima Fidusia tidak hapus karena adanya kepailitan dan atau likuidasi Pemberi Fidusia."

Akan tetapi ketentuan Pasal 56 ayat (1) UUK-PKPU yang mengatakan bahwa:

"Hak eksekusi Kreditor sebagaimana dimaksud dalam Pasal 55 ayat (1) dan hak pihak ketiga untuk menuntut hartanya yang berada dalam penguasaan Debitor pailit atau Kurator ditangguhkan untuk jangka waktu paling lama 90 (sembilan puluh) hari sejak tanggal putusan pernyataan pailit diucapkan.” (Indonesia, 2004)

Berdasarkan ketentuan tersebut, maka kewenangan kreditor separatis untuk mengeksekusi benda jaminan seolah-olah tidak terjadi kepailitan menjadi tertunda karena hak eksekusinya ditangguhkan selama 90 (sembilan puluh) hari untuk kepailitan. Ketentuan penangguhan ini dianggap menjadi tidak konsisten dan dianggap bertentangan dengan ketentuan Pasal 55 ayat (1) (Sularto, 2012). Dalam 
penangguhan ini dapat dijustifikasi oleh asas lex specialis derogat lex generali. Artinya hukum kepailitan menjadi hukum yang khusus terhadap hukum hak jaminan.

Selain itu, terdapat pengaturan pada Pasal 56 ayat (3) UUK-PKPU yang berbunyi:

"Selama jangka waktu penangguhan sebagaimana dimaksud pada ayat (1), Kurator dapat menggunakan harta pailit berupa benda tidak bergerak maupun benda bergerak atau menjual harta pailit yang berupa benda bergerak yang berada dalam penguasaan Kurator dalam rangka kelangsungan usaha Debitor, dalam hal telah diberikan perlindungan yang wajar bagi kepentingan Kreditor atau pihak ketiga sebagaimana dimaksud pada ayat (1)." (Indonesia, 2004)

Dalam penjelasan Pasal 56 ayat (3) UUK-PKPU dijelaskan bahwa harta pailit yang dapat dijual oleh kurator terbatas pada barang persediaan (inventory) dan/atau benda bergerak (current assets), meskipun harta pailit tersebut dibebani dengan hak agunan atas kebendaan. Berdasarkan ketentuan Pasal 56 ayat (1) dan ayat (3) UUK-PKPU kurang memberikan kepastian hukum bagi kreditor separatis dalam mengeksekusi hak jaminannya. Selain itu, diatur juga dalam Pasal 59 ayat (1) UUKPKPU yang berbunyi:

"Dengan tetap memperhatikan ketentuan Pasal 56, Pasal 57, dan Pasal 58, Kreditor pemegang hak sebagaimana dimaksud dalam Pasal 55 ayat (1) harus melaksanakan haknya tersebut dalam jangka waktu paling lambat 2 (dua) bulan setelah dimulainya keadaan insolvensi sebagaimana dimaksud dalam Pasal 178 ayat (1)."

Setelah masa tunggu 90 (sembilan puluh) hari berakhir, Kurator menyerahkan hak mengeksekusi kepada Kreditor separatis dalam jangka waktu 2 (dua) bulan atau 60 hari. Apabila dalam jangka waktu 2 (dua) bulan tidak dapat dieksekusi, maka Kurator harus menuntut diserahkannya benda yang menjadi agunan untuk dijual sesuai dengan cara sebagaimana dimaksud dalam Pasal 185, tanpa mengurangi hak Kreditor pemegang hak tersebut atas hasil penjualan agunan tersebut (Pasal 59 ayat (2)).

Jadi, kewenangan yang diberikan oleh Pasal 56 ayat (3) UUK-PKPU serta Pasal 59 ayat (1) jo Pasal 59 ayat (2) UUK-PKPU kepada Kurator mengakibatkan kewenangan kreditor separatis yang telah diatur dalam UU Hak Tanggungan dan UU Jaminan Fidusia menjadi berubah bahwa Kreditor separatis dapat mengeksekusi seolah-olah tidak terjadi kepailitan sebagaimana diatur dalam Pasal 55 ayat (1) menjadi menjadi tidak berwenang, karena pada akhirnya kewenangan mengeksekusi ada pada Kurator. Oleh karena itu ketentuan Pasal 56 ayat (3) dan Pasal 59 ayat (1) jo Pasal 59 ayat (2) UUK-PKPU ini dapat merugikan kreditor separatis dalam pelaksanaannya. Hal ini yang menjadi fokus dari penelitian ini, bagaimana kedudukan kreditor separatis atas hak jaminan kebendaan dalam proses kepailitan, apakah hak kredior separatis dalam mengekseskusi hak jaminan kebendaan masih dilindungi atau tidak.

Hal ini terdapat pada salah satu kasus Putusan Mahkamah Agung No. 110K/Pdt.Sus.Pailit/2016 yakni kasus William Eduard Daniel selaku Kurator Debitor Pailit, PT Abdi Persada Nusantara (PT APN) tidak melaksanakan kewajibannya yaitu tidak menyerahkan hasil penjualan harta pailit Debitor Pailit kepada para Kreditor Separatis sebagaimana telah ditetapkan oleh Hakim Pengawas.

Berdasarkan hal-hal tersebut diatas, maka rumusan masalah yang akan diteliti adalah: (1) Bagaimana kedudukan kreditor separatis dalam proses kepailitan ditinjau dari UU Hak Tanggungan dan UU Jaminan Fidusia?; (2) Bagaimana akibat hukum dengan terdapatnya pengaturan dalam Pasal 56 ayat (3) UUK-PKPU dan Pasal 59 ayat (1) jo Pasal 59 ayat (2) UUK-PKPU terhadap kreditor separatis? 


\section{B. Metode Penelitian}

Jenis penelitian yang digunakan adalah penelitian yuridis normatif dengan tipe penelitian preskriptif deskriptif, yaitu permasalahan akan dianalisis berdasarkan aturan-aturan hukum secara preskriptif berdasarkan ketentuan perundang-undangan yang berlaku. Data yang digunakan adalah data sekunder yang terdiri dari bahan hukum primer, sekunder dan tersier dengan menggunakan pendekatan undang-undang dan pendekatan kasus. Teknik pengumpulan data dilakukan melalui studi kepustakaan. Bahan hukum primer dan bahan hukum sekunder dikumpulkan dan dianalisis secaa kualitatif untuk menjawab rumusan masalah yang ada.

\section{Hasil dan Pembahasan}

\section{Kedudukan Kreditor Separatis dalam Proses Kepailitan ditinjau dari UU Hak Tanggungan dan UU Jaminan Fidusia}

Dalam pemberesan harta pailit tidak semua kreditor mempunyai kedudukan yang sama. Perbedaan kedudukan kreditor ditentukan oleh jenis kreditornya, yaitu yang pertama, kreditor separatis, merupakan pemegang hak jaminan kebendaan yang diagunkan oleh Debitor; yang kedua kreditor preferen, kreditor yang memiliki hak istimewa yang diberikan oleh undangundang, dan yang ketiga kreditor konkurren, kreditor yang saling bersaing, kreditor yang tidak termasuk golongan kredior separatis atau kreditor preferen yang pelunasan piutangnya setelah dicukupkan dari hasil penjualan atau pelelangan harta pailit setelah diambil bagian dari kreditor separatis dan kreditor preferen.

Berdasarkan UU Hak Tanggungan dan UU Jaminan Fidusia, maka kedudukan kreditor separatis dalam proses kepailitan akan didahulukan walaupun terjadi suatu kepailitan. Hal ini tertera dalam Pasal 27 ayat (3) UU Jaminan Fidusia yang sudah jelas mengatakan bahwa hak yang didahulukan tidak hapus walaupun terjadi kepailitan dan Pasal 21 UU Hak
Tanggungan yang mengatakan bahwa hak kreditor separatis tidak hilang dengan adanya kepailitan dan salah satu hak kreditor separatis adalah hak untuk mendahului dari kreditor-kreditor lainnya yang tercantum pada Pasal 20 ayat (1) UU Hak Tanggungan yang berbunyi:

"Apabila debitor cidera janji, maka berdasarkan: (a) hak pemegang Hak Tanggungan pertama untuk menjual obyek Hak Tanggungan sebagaimana dimaksud dalam Pasal 6, atau (b) titel eksekutorial yang terdapat dalam sertipikat Hak Tanggungan sebagaimana dimaksud dalam Pasal 14 ayat (2), obyek Hak Tanggungan dijual melalui pelelangan umum menurut tata cara yang ditentukan dalam peraturan perundang-undangan untuk pelunasan piutang pemegang Hak Tanggungan dengan hak mendahului dari pada kreditor-kreditor lainnya."

Selain itu, dalam penjelasan Pasal 21 UU Hak Tanggungan mengatakan bahwa ketentuan ini lebih menegaskan keutamaan kedudukan pemegang hak tanggungan dengan mengecualikan berlakunya akibat kepailitan pemberi hak tanggungan terhadap obyek hak tanggungan. Di dalam penjelasan Pasal 21 UU Hak Tanggungan ditetapkan bahwa ketentuan ini lebih menguatkan kedudukan pemegang hak tanggungan dengan mengecualikan berlakunya akibat kepailitan pemberi hak tanggungan terhadap obyek hak tanggungan. Sedangkan pengaturan kedudukan kreditor separatis dalam UU Jaminan Fidusia dalam Pasal 27 ayat (3) pada pokoknya mengatur bahwa kreditor separatis didahulukan kedudukannya apabila debitor dinyatakan pailit. Dalam penjelasan Pasal 27 ayat (3) UU Jaminan Fidusia ditetapkan bahwa ketentuan dalam ayat ini berhubungan dengan ketentuan bahwa jaminan fidusia merupakan hak agunan atas kebendaan bagi pelunasan utang. Secara normatif baik UU Hak Tanggungan maupun UU Fidusia menjamin hak kreditor separatis untuk mengeksekusi hak kebendaan yang 
dikuasainya sebagai jaminan atas pembayaran piutangnya walaupun terjadi kepailitan.

Dan hal ini juga diatur didalam UUKPKPU yaitu Pasal 55 ayat (1) yang menetapkan bahwa kreditor separatis dapat melakukan eksekusi seolah-olah tidak terjadi kepailitan. Demikian bunyi Pasal 55 ayat (1) bahwa "Dengan tetap memperhatikan ketentuan sebagai-mana dimaksud dalam Pasal 57, Pasal 57, dan Pasal 58, setiap Kreditor pemegang gadai, jaminan fidusia, hak Tanggungan, hipotek atau hak agunan atas kebendaan lainnya, dapat mengeksekusi haknya seolah-olah tidak terjadi kepailitan.“ Sularto mengatakan bahwa berdasarkan ketentuan Pasal 55 ayat (1) tersebut bahwa kreditor separatis dapat menjual sendiri barang-barang yang menjadi jaminan piutangnya yang ada dalam penguasaannya (Sularto, 2012).

Akan tetapi apabila ditelaah lebih lanjut regim kepailitan Indonesia dengan adanya ketentuan Pasal 56 ayat (1) UUK-PKPU yang menetapkan bahwa hak eksekusi kreditor separatis ditangguhkan selama jangka waktu 90 (sembilan puluh) hari sejak putusan pailit. Artinya, ketentuan Pasal 55 ayat (1) tidak dapat serta merta langsung dieksekusi, karena menunggu masa penangguhannya tersebut. Dengan adanya ketentuan Pasal 56 ayat (1) UUK-PKPU tidak sejalan dengan hak separatis yang diberikan oleh UU Hak Tanggungan dan UU Jaminan Fidusia yang diakui juga oleh Pasal 55 ayat (1) UUK-PKPU ini.

Bagaimana sebenarnya kedudukan kreditor separatis jika ditinjau dari aspek UU Hak Tanggungan dan UU Jaminan Fidusia? Apakah hak mengeksekusi sebagai kreditor separatis hilang dalam proses kepailitan?

Jika ditelaah ketentuan Pasal 56 ayat (1) seolah-olah Kreditor separatis kehilangan haknya untuk mengeksekusi barang atau benda yang berada dalam penguasaannya. Ketentuan Pasal 56 ayat (1) menetapkan bahwa Hak eksekusi Kreditor sebagaimana dimaksud dalam Pasal 55 ayat (1) dan hak pihak ketiga untuk menuntut hartanya yang berada dalam penguasaan Debitor Pailit atau
Kurator, ditangguhkan untuk jangka waktu paling lama 90 (sembilan puluh) hari sejak tanggal putusan pernyataan pailit diucapkan.

Akan tetapi sebenarnya kreditor separatis tidak kehilangan haknya untuk mengeksekusi, hanya ditunda selama 90 (sembilan puluh) hari. Oleh karena itu perlu diketahui tujuan UUK-PKPU mengatur penundaan hak eksekusi kreditor separatis tersebut. Adapun hakekat tujuan penangguhan sebagaimana diatur dalam Pasal 56 ayat (1) UUK-PKPU antara lain adalah: (a) Untuk memperbesar kemungkinan tercapai perdamaian, atau (b) Untuk memperbesar kemungkinan mengoptimalkan harta pailit, atau (c) Untuk memungkinkan kurator melaksanakan tugasnya secara optimal.

Menurut hemat Penulis, tujuan adanya Pasal 56 ayat (1) UUK-PKPU memang benar karena dalam jangka waktu 90 (sembilan puluh) hari tersebut dapat digunakan bagi debitor untuk mengajukan rencana perdamaian. Karena memang UUKPKPU ini memberikan kesempatan bagi debitor untuk berdamai dengan kreditornya. Namun, apabila debitor pailit rencana perdamaiannya gagal dalam proses PKPU maka tidak akan ada lagi rencana perdamaian yang kedua. Selain itu, menurut Sutan Remy Sjahdeini upaya perdamaian seyogyanya hanya ada sebelum penyataan pailit diputuskan oleh pengadilan dan setelah pernyataan pailit dijatuhkan oleh pengadilan, tidak ada lagi upaya perdamaian (Sjahdeini, 2016). Jadi, seharusnya reorganisasi adalah yang pertama-tama dan terlebih dahulu harus diusahakan oleh para kreditor dan debitor sebelum diajukan permohonan pernyataan pailit terhadap debitor. Sehingga, seharusnya ketika pernyataan pailit sudah diputuskan, sudah tidak terdapat lagi perdamaian karena pailit adalah ultimum remedium.

Dalam jangka waktu 90 (sembilan puluh) hari kurator akan melakukan tugasnya untuk mengoptimalkan harta pailit dan melakukan tugasnya secara optimal seperti melakukan pendataan harta pailit debitor pailit serta debitor pailit dapat 
mengajukan upaya perdamaian kepada kreditor konkuren. Setelah masa menunggu selama 90 (semblan puluh) hari berakhir, kreditor separatis dapat mengeksekusi sendiri hak jaminan kebendaan yang dikuasainya. Ketentuan Pasal 55 ayat (1) dapat dilaksanakan sendiri oleh kreditor separatis setelah jangka waktu masa tunggu 90 (sembilan puluh) hari berakhir. Jadi, ketentuan Pasal 21 UU Hak Tanggungan dan Pasal 27 ayat (3) UU Jaminan Fidusia dapat dieksekusi oleh kreditor separatis setelah menunggu masa penangguhan eksekusi jaminannya selama 90 (sembilan puluh) hari seperti yang diatur dalam Pasal 56 ayat (1) UUK-PKPU berakhir.

Dengan berakhirnya masa tunggu tersebut kreditor separatis dapat mengeksekusi hak jaminannya dan kreditor separatis diberi waktu selama dua bulan sebagaimana diatur dalam Pasal 59 ayat (1) UUK-PKPU, yaitu bahwa pemegang hak jaminan harus melaksanakan hak eksekusi dalam jangka waku paling lambat dua bulan 2 (dua) bulan sejak dimulainya keadaan insolvensi.

Selain itu jika dilihat dari aspek hirarkhi perundang-undangan, baik dalam UU Hak Tanggungan dan UU Jaminan Fidusia tidak terdapat ketentuan yang menyebutkan bahwa kreditor separatis tunduk pada UUKPKPU, karena UUK-PKPU, UU Hak Tanggungan dan UU Fidusia mempunyai kedudukan yang sama, yaitu sama-sama undang-undang.

Oleh karena itu untuk dapat melihat penerapan hukum mana yang seharusnya berlaku, maka dapat digunakan asas preferensi. Asas preferensi adalah asas hukum yang menunjuk hukum mana yang harus didahulukan (diberlakukan) jika dalam suatu peristiwa hukum terkait atau terlanggar beberapa peraturan (Agustina, 2015). Ada beberapa asas preferensi sebagai berikut: (a) Lex superiori derogat legi inferiori, yaitu peraturan perundangundangan yang lebih tinggi akan mengesampingkan peraturan perundangundangan yang lebih rendah; (b) Lex specialis derogat legi generali, yaitu peraturan yang khusus akan mengesampingkan peraturan yang umum sifatnya atau peraturan yang khususlah yang harus didahulukan; (c) Lex posteriori derogat legi priori, yaitu peraturan yang baru mengalahkan atau mengesampingkan peraturan yang lama.

Ketiga asas preferensi tersebut di atas akan digunakan sebagai alat untuk menganalisis kedudukan penerapan hak eksekusi kreditor separatis apakah berdasarkan UUK-PKPU, atau UU Hak Tanggungan dan UU Jaminan Fidusia.

Seperti yang diketahui bahwa apabila kita mendasarkan pilihan hukum kepada asas lex superiori derogat legi inferiori, maka kita merujuk kepada Undang-undang Nomor 12 Tahun 2011 tentang Pembentukan Peraturan Perundangundangan yakni pada Pasal 7 ayat (1) yang berbunyi:

"Jenis dan hierarki Peraturan Perundang-undangan adalah sebagai berikut: (1) Undang-Undang Dasar Negara Republik Indonesia Tahun 1945; (2) Ketetapan Majelis Permusyawaratan Rakyat; (3) UndangUndang/Peraturan Pemerintah Pengganti Undang-Undang;

Peraturan Pemerintah; (5) Peraturan Presiden; (6) Peraturan Daerah.”

Berdasarkan hierarki peraturan perundang-undangan di atas, maka UUKPKPU, UU Hak Tanggungan dan UU Jaminan Fidusia memiliki kedudukan hukum yang sama atau setara yakni pada tingkat undang-undang. Kekuatan pelaksanaannya dari asas lex superiori derogat legi inferiori menyatakan bahwa UUK-PKPU, UU Hak Tanggungan dan UU Jaminan Fidusia sama kedudukannya. Jadi diantara ketiga undang-undang tersebut tidak terdapat ketidakcocokan untuk menggunakan asas lex superiori derogat legi inferiori karena dalam hal ini tidak ada peraturan yang lebih superior atau yang lebih tinggi derajatnya. Jika berdasarkan asas lex superiori derogat legi inferiori tidaklah terdapat jawaban mengenai pilihan 
hukum mana yang seharusnya digunakan., melainkan seharusnya diterapkan secara sama.

Akan tetapi apabila berdasarkan pilihan hukum kepada asas lex posterior derogate legi priori, maka yang berlaku adalah UUKPKPU. Hal ini disebabkan karena UUKPKPU diundangkan pada tahun 2004, sedangkan UU Hak Tanggungan diundangkan pada tahun 1996 dan UU Jaminan Fidusia diundangkan pada tahun 1999. Maka, berdasarkan hal tersebut UUKPKPU yang lebih baru diundangkan dibandingkan dengan UU Jaminan Fidusia dan UU Hak Tanggungan.

Kemudian apabila diterapkan asas lex specialis derogat lex generalis, maka UU yang berlaku adalah UUK-PKPU, karena UUK-PKPU ini mengatur mengenai kepailitan secara keseluruhan, termasuk tentang masa tunggu bagi kreditor separatis untuk mengeksekusi hak kebendaan yang dikuasainya. Selain itu, dalam Peraturan Menteri Keuangan Nomor 27/PMK.06/2016 tentang Petunjuk Pelaksanaan Lelang (Selanjutnya disebut Permenkeu 27/2016) yakni pada Pasal 15 disebutkan bahwa dalam hal terdapat permohonan lelang eksekusi dari kreditor pemegang hak agunan kebendaan yang terkait dengan putusan pernyataan pailit, maka pelaksanaan lelang dilakukan dengan memperhatikan UndangUndang Kepailitan.

Asas preferensi tersebut memberikan gambaran dalam penerapan hak eksekusi kreditor separatis yang dijamin oleh UU Hak Tagungan, UU Jaminan Fidusia tetap dapat dilaksanakan walaupun ditunda selama jangka waktu 90 (sembilan puluh) hari (Pasal 56 ayat (1) UUK-PKPU. Hak eksekusi tersebut dapat dilakukan oleh kreditor separatis setelah jangka waktu 90 (sembilan puluh) hari berakhir, dan diberikan waktu 2 (dua) bulan untuk mengeksekusinya (Pasal 59 ayat (1)). Karena kepailitan merupakan sita umum, maka jika kreditor separatis dalam jangka waktu 6 tidak dapat mengeksekusinya, jaminan kebendaan tersebut diserahkan kepada kurator untuk melakukan eksekusi.
Hasil penjualan atau lelang dari hak jaminan kebendaan yang dilakukan oleh kurator tersebut tetap kreditor separatis mendapatkan pembayaran pertama (didahulukan) dibandingkan dengan kreditor lain yang harus menunggu pemberesan dari kurator. Di samping itu, dalam UUK-PKPU mengenal asas keseimbangan yang mana penangguhan dalam Pasal 56 ayat (1) dan Pasal 56 ayat (3) UUK-PKPU dapatlah dihapuskan atau dipercepat sesuai yang diatur dalam Pasal 57 (Sutedi, 2010).

\section{Akibat Hukum dengan Terdapatnya Ketentuan Pasal 56 ayat (3) dan Pasal 59 ayat (1) jo Pasal 59 ayat (2) UUK- PKPU}

Sebagaimana dijelaskan sebelumnya bahwa kreditor separatis ditangguhkan hak eksekusinya selama 90 (sembilan puluh) hari. Dalam masa waktu pengangguhan kurator dapat menggunakan atau menjual harta pailit guna kelangsungan usaha debitor. Hal ini diatur dalam Pasal 56 ayat (3) UUK-PKPU yang menetapkan bahwa:

"Selama jangka waktu penangguhan sebagaimana dimaksud pada ayat (1), Kurator dapat menggunakan harta pailit berupa benda tidak bergerak maupun benda bergerak atau menjual harta pailit yang berupa benda bergerak yang berada dalam penguasaan Kurator dalam rangka kelangsungan usaha Debitor, dalam hal telah diberikan perlindungan yang wajar bagi kepentingan Kreditor atau pihak ketiga sebagaimana dimaksud pada ayat (1)." (Indonesia, 2004)

Dalam penjelasan Pasal 56 ayat (3) UUK-PKPU dijelaskan bahwa harta pailit yang dapat dijual oleh kurator terbatas pada barang persediaan (inventory) dan/atau benda bergerak (current assets), meskipun harta pailit tersebut dibebani dengan hak agunan atas kebendaan. Selain itu, dalam Pasal 56 ayat (3) ini juga disebutkan bahwa kreditor separatis harus diberikan perlindungan yang wajar yang dimaksud dengan perlindungan yang wajar adalah 
perlindungan yang diberikan untuk melindungi kepentingan kreditor atau pihak ketiga yang haknya ditangguhkan. Perlindungan tersebut dapat berupa: (1) Ganti rugi atas terjadinya penurunan nilai harta pailit; (2) Hasil penjualan bersih; (3) Hak kebendaan pengganti; atau (4) Imbalan yang wajar dan adil serta pembayaran tunai (utang yang dijamin) lainnya.

Berdasarkan hal tersebut maka menurut hemat Penulis Pasal 56 ayat (3) UUK-PKPU kurang memberikan jaminan kepastian hukum bagi pelaksanaan eksekusi kreditor separatis karena harta yang dibebani jaminan pun termasuk harta yang dapat dieksekusi oleh kurator. Selain itu, Pasal 56 ayat (3) UUK-PKPU terlihat mengingkari hak separatis yang dimiliki kreditor separatis karena menentukan bahwa barang yang dibebani dengan hak jaminan merupakan harta pailit dan dapat dieksekusi oleh kurator demi kepentingan debitor. Artinya bahwa undang-undang kepailitan tidak memisahkan benda-benda yang dibebani hak jaminan sebagai benda-benda yang tidak termasuk ke dalam harta pailit.

Setelah waktu penundaan eksekusi hak jaminan 90 hari berakhir, Pasal 59 ayat (1) jo Pasal 59 ayat (2) UUK-PKPU ini mengatur bahwa kreditor separatis haruslah melakukan eksekusi terhadap jaminannya dalam jangka waktu 2 (dua) bulan setelah dimulainya keadaan insolvensi dan apabila dalam jangka waktu 2 (dua) bulan setelah keadaan insolvensi, kreditor separatis tidak dapat melakukan eksekusi terhadap jaminannya, maka yang akan melakukan eksekusi adalah kurator. Berdasarkan Pasal 178 ayat (1) UUK-PKPU, keadaan insolvensi didapatkan secara otomatis apabila dalam rapat pencocokan piutang tidak ditawarkan rencana perdamaian atau rencana perdamaian yang ditawarkan tidak diterima, atau pengesahan perdamaian ditolak berdasarkan putusan yang telah memperoleh kekuatan hukum tetap.

Dengan terdapatnya pengaturan pada Pasal 56 ayat (3) dan Pasal 59 ayat (1) jo Pasal 59 ayat (2) UUK-PKPU yang memberikan hak eksekutorial kepada kurator yang seharusnya hak eksekutorial tersebut adalah dilakukan oleh kreditor separatis memberikan kesan bahwa kewenangan kreditor separatis seolah-olah dirampas oleh UUK-PKPU. Seharusnya, hak eksekusi yang dimiliki oleh kreditor separatis tidaklah berpindah kepada kurator. Menurut Sutan Remy Sjahdeini, sudah merupakan asas universal bahwa benda yang dibebani dengan hak jaminan bukan merupakan harta pailit. Dengan kata lain, benda yang dibebani oleh hak jaminan tidak pernah hak eksekusinya menjadi hak kurator, tetapi tetap menjadi hak kreditor separatis (Sutan Remi Sjahdeini, 2016). Hal ini sebenarnya bertolakbelakang dengan ketentuan dalam Pasal 6 UU Hak Tanggungan yang berbunyi: "Apabila debitor cidera janji, pemegang Hak Tanggungan pertama mempunyai hak untuk menjual obyek Hak Tanggungan atas kekuasaan sendiri melalui pelelangan umum serta mengambil pelunasan piutangnya dari hasil penjualan tersebut." dan Pasal 15 ayat (3) UU Jaminan Fidusia yang berbunyi: "Apabila debitor cidera janji, Penerima Fidusia mempunyai hak untuk menjual Benda yang menjadi objek Jaminan Fidusia atas kekuasaannya sendiri." Jadi, seharusnya memang hak untuk menjual benda atau melakukan eksekusi adalah kewenangan yang dimiliki oleh kreditor separatis bukan oleh kurator.

Sebenarnya ketentuan Pasal 56 ayat (3) dan Pasal 59 ayat (1) jo Pasal 59 ayat (2) UUK-PKPU sudah benar, namun dikarenakan terdapatnya celah dalam Pasal 56 ayat (3) dan Pasal 59 ayat (1) jo Pasal 59 ayat (2) UUK-PKPU ini membuat celah tersebut dimanfaatkan oleh oknum yang tidak bertanggung jawab. Hal ini dikarenakan masih adanya kurator-kurator nakal yang memanfaatkan celah ini untuk mendapatkan keuntungan pribadinya. Serta dengan terdapatnya celah pada Pasal 56 ayat (3) dan Pasal 59 ayat (1) jo Pasal 59 ayat (2) UUK-PKPU ini lebih mendukung bahwasanya UUK-PKPU ini justru merugikan kreditor separatis karena hak eksekutorial yang diberikan oleh UU Hak 
Tanggungan dan UU Jaminan Fidusia, karena yang diberlakukan adalah UUKPKPU yang mana hak eksekutorial dari kreditor separatis beralih kepada kurator. Walapun hak eksekutorial beralih kepada kurator, sepanjang hasil pelelangan hak jaminan diberikan terlebih dahulu kepada kreditor separatis, berarti hak kreditor separatis dilindungi oleh Undang-undang Hak Tanggungan dan Undang-undang Fidusia serta UUK-PKPU. Karena pada faktanya, hasil eksekusi yang dilakukan oleh kurator tidak sepenuhnya diberikan kepada kreditor separatis melainkan dapat dialokasikan untuk hal-hal lainnya, misalnya pembayaran kreditor preferen yang harus didahulukan. Dalam hal ini Penulis akan memberikan beberapa contoh kasus yang menunjukan bahwa dengan terdapatnya ketentuan Pasal 56 ayat (3) dan Pasal 59 ayat (1) jo Pasal 59 ayat (2) UUK-PKPU yang merugikan kreditor separatis:

\section{a. Putusan Mahkamah Agung Nomor 110K/Pdt.Sus.Pailit/2016}

Para pihak dalam kasus ini adalah William Eduard Daniel sebagai Pemohon Kasasi/ Tergugat dengan Goldenpointe Overseas Limited sebagai Termohon Kasasi/ Penggugat. Jadi, William Eduard Daniel merupakan kurator yang mengelola PT Abdi Persada Nusantara (PT. APN) yang merupakan perusahaan yang telah pailit melalui Putusan Pengadilan Niaga Surabaya Nomor 10/Pailit/2008/PN.Niaga.Sby, tanggal 11 Agustus 2008. Hakim Pengawas telah mengeluarkan Penetapan Pengadilan Niaga Surabaya Nomor 10/Pailit/2008/PN.Niaga.Sby tanggal 10 November 2009 yang salah satu amarnya menetapkan Penggugat sebagai Kreditor Separatis dan Kreditor Konkuren, serta berhak atas hasil penjualan harta pailit PT APN dengan rincian sebagai berikut: (1) Hak selaku Kreditor Separatis sejumlah Rp. 19.153.761.334,37. dan; (2) Hak selaku
Kreditor Konkuren: sejumlah Rp. 5.028.307.271,71.

Terhadap Penetapan Hakim Pengawas, Penggugat telah mengajukan perlawanan yang pada akhirnya diputus oleh Mahkamah Agung RI melalui Putusan Mahkamah Agung RI Nomor 123K/Pdt.Sus/2010 tanggal 12 Mei 2010 (Putusan MARI). Dengan adanya Putusan MARI yang telah berkekuatan hukum tetap, maka Daftar Pembagian Harta Pailit harus dilaksanakan. Sehingga, terhitung sejak tanggal 12 Mei 2010, Tergugat memiliki kewajiban hukum untuk membayarkan hak-hak Penggugat. Kemudian Penggugat memberikan surat permintaan kepada Tergugat sehingga pada akhirnya pada tanggal 4 November 2011, Tergugat membayar hak kreditor sebesar USD 1.710.157atau setara dengan Rp. 14.980.975.320dengan kurs 1 USD = Rp. 8760,00 yang menyebabkan sisa kewajiban Tergugat menjadi: (1) Hak sebagai Kreditor Separatis sebesar Rp. 3.830.752.266,80; (2) Hak sebagai Kreditor Konkuren sebesar Rp. 5.028.307.271,71.

Dikarenakan masih terdapat hak Penggugat yang belum dibayarkan oleh Tergugat, maka Penggugat tetap mengirimkan surat permintaan yang dimana surat permintaan tersebut tidak dihiraukan oleh Tergugat sehingga pada akhirnya Penggugat mengirimkan Surat Peringatan I yang membuat Tergugat membayarkan sisa kewajibannya pada tanggal 1 Agustus 2012sebagai kreditor konkuren sebesar USD 423,436 atau setara dengan Rp. 4.022. 645. 817, 38 dengan kurs $1 U S D=$ Rp.9500,00 yang menyebabkan sisa kewajiban Tergugat menjadi: (1) Hak sebagai kreditor separatis Rp. 3.830.752.266,80; (2) Hak sebagai kreditor konkuren Rp. 1.005. 661. 454,33.

Penggugat telah berulang kali meminta kepada Tergugat untuk melaksanakan kewajibannya sesuai dengan daftar pembagian namun tidak 
dihiraukan oleh Tergugat, sehingga akhirnya Penggugat memberikan Surat Peringatan II yang tidak juga dihiraukan oleh Tergugat. Oleh karena adanya ketidakpastian hukum, Penggugat berupaya untuk memperoleh informasi dan kejelasan mengenai keadaan harta pailit PT APN kepada Hakim Pengawas. Akan tetapi, berdasarkan informasi yang diperoleh Penggugat dari Hakim Pengawas, terungkap bahwa Tergugat sama sekali belum menyampaikan laporan-laporannya mengenai keadaan harta pailit kepada Hakim Pengawas. Padahal, Tergugat diwajibkan secara hukum untuk menyampaikan laporannya setiap 3 (tiga) bulan kepada hakim pengawas mengenai keadaan harta pailit dan pelaksanaan tugasnya. Dengan fakta tersebut, maka jelas bahwa Tergugat kembali tidak melakukan kewajiban hukumnya selaku kurator dalam pengurusan dan pemberesan.

Berdasarkan contoh kasus ini, dapat kita lihat bahwa jangka waktu Penggugat mendapatkan haknya sebagai kreditor separatis dan kreditor konkuren begitu lama dan berlarut-larut, Tergugat selaku kurator telah menunda dan tidak membayarkan secara segera dan penuh hak-hak Penggugat selaku kreditor separatis dan kreditor konkuren atas hasil penjualan harta pailit PT APN sesuai dengan Daftar Pembagian Harta yang ada. Pembayaran yang dilakukan oleh Tergugat selaku kurator tidak sesuai dengan yang dijadwalkan dalam Daftar Pembagian Harta yang menimbulkan ketidakpastian hukum yang merugikan Penggugat yang memiliki hak sebagai kreditor separatis dan kreditor konkuren. Apabila dalam hal ini Penggugat selaku kreditor separatis yang melakukan eksekusi sendiri atas jaminan yang dimilikinya, maka tentu saja hasil penjualan hak jaminannya langsung didapatkan olehnya dan tidak perlu menunggu terlalu lama untuk mendapatkan hasil penjualan tersebut dan Penggugat hanya harus menunggu haknya sebagai kreditor konkuren. Jika, didasarkan pada Pasal 56 ayat (1) UU Kepailitan dan PKPU jelas bahwa kreditor separatis hanya perlu menunggu 90 (sembilan puluh) hari untuk dapat mengeksekusi hak jaminannya. Namun, dengan terdapatnya Pasal 56 ayat (3) dan Pasal 59 ayat (1) jo Pasal 59 ayat (2) UU Kepailitan dan PKPU yang menyebabkan perpindahan kewenangan eksekusi hak jaminan dari kreditor separatis kepada kurator memberikan kerugian yang jauh lebih besar kepada kreditor separatis, karena kreditor separatis harus menunggu jangka waktu yang lama untuk mendapatkan haknya seperti dalam contoh kasus ini yang mana kreditor separatis harus menunggu sekitar 4 (empat) tahun untuk mendapatkan sebagian haknya saja dan menunggu sekitar 8 (delapan) tahun untuk mendapatkan seluruh haknya setelah Putusan Mahkamah Agung yang berkekuatan hukum tetap.

\section{b. Putusan Mahkamah Agung Nomor 816K/Pdt.Sus.Pailit/2015}

Para pihak dalam putusan ini adalah PT. Bank Rakyat Indonesia (Persero) Tbk selaku Pemohon Kasasi atau Pelawan dengan CV Joyo Mulyo (Budi Sudjatmiko Susilo dan Inggrid Dianita Soesilo) dan Para Karyawan CV Joyo Mulyo selaku Termohon Kasasi atau Terlawan. Jadi, berdasarkan Putusan Pengadilan Niaga Surabaya Nomor 37/Pailit/2012/PN.Niaga.Sby (Putusan Pengadilan Niaga 37/2012), tanggal 4 Februari 2013, CV Joyo Mulyo dinyatakan dalam keadaan pailit dengan segala akibat hukumnya dan Tommi Siregar, S.H., LL.M ditunjuk sebagai Kurator CV Joyo Mulyo. Pada 14 Maret 2013 telah diadakan Rapat Pencocokan Piutang di Pengadilan Negeri Surabaya yang dimana Pemohon Kasasi dengan total tagihan sebesar Rp. 35.786.862.128,08 telah dimasukkan ke 
dalam Daftar Piutang Tetap Diakui. Pada 13 Mei 2013, CV Joyo Mulyo, dinyatakan dalam keadaan insolvensi sebagaimana telah dituangkan ke dalam Penetapan Hakim Pengawas Nomor 37/Pailit/2012/PN.Niaga.Sby.

Berdasarkan surat Kurator Nomor 044/Kurator- JM/09/2014, tanggal 22 September 2014 yang ditujukan kepada Pemohon Kasasi, Tommi Siregar, S.H, LL.M., selaku Kurator terdahulu CV Joyo Mulyo menyatakan mengundurkan diri. Oleh karena itu, Pemohon Kasasi mengajukan permohonan Pengangkatan Kurator Pengganti CV Joyo Mulyo.Terhadap yang kami ajukan tersebut di atas, berdasarkan Penetapan Majelis Hakim Perkara Nomor 37/Pailit/2012/PN.Niaga.Sby, tanggal 12 November 2014, diangkat Kurator Pengganti yaitu Muhamad Idris, S.Sos., S.H., dan Anna Lydia Yusuf, S.E., S.H., untuk melanjutkan tugas Kurator sebelumnya. Tim Kurator CV Joyo Mulyo, melakukan pemberesan harta pailit dengan melaksanakan penjualan umum secara lelang, dengan rincian yaitu:

\section{a. KPKNL Sidoarjo:}

Adapun objek yang akan dilelang berupa benda tetap dan benda tidak tetap dalam 1 (satu) paket dengan kondisi apa adanya yaitu benda tetap berupa 6 (enam) bidang tanah dalam 1 (satu) hamparan berikut bangunan eks pabrik yang berdiri di atasnya, terletak di Jalan Sawunggaling I Nomor 5, Ds. Jemundo, Kec. Taman, Kab. Sidoarjo, Jawa Timur dengan total luas $5.347 \mathrm{~m}^{2}$, yang kesemuanya atas nama Budi Sudjatmiko Susilo, yang diletakkan Hak Tanggungan dan benda tidak tetap berupa serangkaian mesinmesin dan peralatan produksi eks pabrik CV. Joyo Mulyo yang diletakkan Jaminan Fidusia dengan terjual pada lelang ulang kedua pada 27 April 2015 dengan harga limit Rp. 10.000.000.000,00 dengan hasil laku terjual dengan harga Rp. 10.002.000.000,00.

\section{b. KPKNL Surabaya}

Adapun objek yang akan dilelang berupa benda tetap dengan kondisi apa adanya yaitu sebidang tanah berikut bangunan rumah yang berdiri di atasnya, terletak di Jalan Kesumba Nomor 17, Kecamatan Tambak sari, Kelurahan Tambaksari, Surabaya, Jawa Timur dengan total luas $263 \mathrm{~m}^{2}$, dengan bukti kepemilikan Sertifikat Hak Milik (SHM) Nomor 126 atas nama Budi Sudjatmiko Susilo yang diletakkan Hak Tanggungan dengan terjual pada lelang ulang kedua pada 6 Mei 2015 dengan harga Rp. 2.100.000.000,00 dengan hasil laku terjual dengan harga $\mathrm{Rp}$. 2.100.000.000,00.

Tim Kurator telah membuat Daftar Pembagian Kreditor CV Joyo Mulyo dan telah disahkan oleh Hakim Pengawas tanggal 7 Mei 2015 sebagaimana dituangkan ke dalam Penetapan Hakim Pengawas.Daftar Pembagian Kreditor CV Joyo Mulyo telah diumumkan oleh Tim Kurator pada 11 Mei 2015 diharian surat kabar Republika dan Memorandum Surabaya. Dalam Pengumuman Daftar Pembagian Kreditor CV Joyo Mulyo, terdapat jangka waktu mengajukan keberatan yaitu 7 (tujuh) hari sejak diumumkan. Kemudian terhadap Daftar Pembagian Kreditor CV Joyo Mulyodengan ini Pemohon Kasasi mengajukan keberatan terhadap pembagian Kreditor Preferen yaitu Mantan Karyawan CV Joyo Mulyo yang mendapatkan pembagian sebesar Rp. 4.699.559.835,00 atau $100 \%$ dari tagihan. Bahwa kami juga mempertanyakan tagihan Kreditor Preferen yaitu mantan Karyawan CV Joyo Mulyo sebesar Rp. 4.699.559.835,00 yang dicatat dan 
dimasukkan ke dalam Daftar Piutang Tetap Diakui oleh Kurator terdahulu. Berdasarkan Putusan Mahkamah Konstitusi Nomor 67/PUU-XI/2013 tanggal 11 September 2014 yang mengadili perkara Konstitusi tingkat Pertama dan Terakhir menjatuhkan Putusan dalam perkara Pengujian Undang-Undang Nomor 13 Tahun 2003 tentang Ketenagakerjaan Pasal 95 ayat (4) amar putusan sebagai berikut:

"Pembayaran upah pekerja/buruh yang terutang didahulukan atas semua jenis kreditor termasuk atas tagihan kreditor separatis, tagihan hak negara, kantor lelang dan badan umum yang dibentuk oleh pemerintah, sedangkan bayaran hak-hak negara, kantor lelang dan badan umum yang dibentuk Pemerintah kecuali tagihan dari Kreditor Separatis" (Indonesia, 2003)

Jadi, Putusan Mahkamah Agung Nomor $\quad 816 K / P d t . S u s . P a i l i t / 2015$ Majelis Hakim memutuskan bahwa permohonan keberatan PT Bank Rakyat Indonesia ditolak dengan alasan Pengadilan Niaga tidak salah menerapkan hukum.

Berdasarkan contoh kasus ini, menurut Penulis pengaturan bahwa kedudukan gaji karyawan berada diatas kreditor separatis adalah keliru dikarenakan hak jaminan yang dimiliki oleh kreditor separatis seharusnya diberikan seutuhnya kepada kreditor separatis dan tidak diberikan kepada karyawan. Karena tujuan adanya jaminan yang dimiliki oleh kreditor separatis adalah untuk memberikan perlindungan hukum bagi kreditor separatis yaitu guna pembayaran piutangnya apabila debitor tidak membayar kewajibannya. Apabila hak kreditor separatis diberikan kepada karyawan tentu saja itu sangatlah tidak adil dan merugikan kreditor separatis, karena memang sejak awal perjanjian utang piutang antara debitor dan kreditor separatis, hak jaminan tersebut diperuntukkan membayar utang debitor kepada kreditor separatis apabila debitor wanprestasi. Namun, karena dengan adanya Putusan Mahkamah Konstitusi yang mengatakan bahwa kedudukan gaji karyawan berada di atas kreditor separatis, maka tentu saja ketentuan tersebut harus diikuti.

\section{Simpulan}

Berdasarkan hasil pembahasan di atas dapat disimpulkan bahwa dalam UU Hak Tanggungan dan UU Jaminan Fidusia dijelaskan bahwa hak kreditor separatis tidak hilang dengan adanya kepailitan dan salah satu haknya adalah hak untuk didahulukan dari kreditor-kreditor yang lain. Hal ini sesuai dengan ketentuan Pasal 55 ayat (1) UUK-PKPU yang mengatakan bahwa kreditor separatis dapat mengeksekusi haknya seolah-olah tidak terjadi kepailitan. Namun, pada ketentuan selanjutnya yakni pada Pasal 56 ayat (1) UUK-PKPU terlihat kontradiktif yang mengatakan bahwa hak eksekusi kreditor separatis ditangguhkan selama 90 (sembilan puluh) hari setelah putusan pailit. Jika dilihat UUK-PKPU ini memang terlihat seolah-olah tidak mendahulukan kreditor separatis, namun sebenarnya kedudukan kreditor separatis tetap dijamin dan didahulukan karena walaupun ditangguhkan kreditor separatis tetap mendapatkan pembayaran utangnya terlebih dahulu dibandingkan dengan kreditor lainnya, bahkan hak mengeksekusi hak jaminan diserahkan kepada kreditor separatis setelah masa tunggu 90 (sembilan puluh) hari telah berakhir, yaitu diberikan jangka waktu selama 60 (enam puluh) hari.

Ketentuan Pasal 56 ayat (3) UUKPKPU menjelaskan bahwa selama masa penangguhan 90 (sembilan puluh) hari, kurator dapat menjual harta pailit yang berada dalam penguasaan kurator dan dalam penjelasan Pasal 56 ayat (3) UUK-PKPU dijelaskan bahwa harta pailit yang dapat dijual oleh kurator termasuk harta pailit 
yang dibebani dengan agunan. Ketentuan Pasal 59 ayat (1) jo Pasal 59 ayat (2) UUKPKPU mengatur bahwa apabila kreditor separatis harus melakukan eksekusi terhadap jaminannya dalam jangka waktu 2 (dua) bulan setelah dinyatakan keadaan insolvensi dan apabila kreditor separatis tidak dapat melakukan eksekusi terhadap hak jaminannya, maka yang akan melakukan eksekusi adalah kurator. Dengan terdapatnya pengaturan pada Pasal 56 ayat (3) dan Pasal 59 ayat (1) jo Pasal 59 ayat (2) UUK-PKPU, maka akibat hukumnya adalah adanya perpindahan kewenangan hak eksekutorial dari kreditor separatis kepada kurator.

Kedudukan kreditor separatis sebagai pemegang hak jaminan dalam proses kepailitan, kurator harus memberikan perlindungan hukum yang jelas dan pasti untuk pelunasan piutangnya, jangan sampai seperti kurator bertindak seperti contoh kasus-kasus diatas. Oleh karena itu ketentuan Pasal 56 ayat (3) UUK-PKPU yakni pada bagian penjelasannya perlu direvisi, yaitu mengenai pengalihan hak kebendaan yang dilakukan kurator, hak kebendaan tersebut dianggap berakhir demi hukum. Berakhirnya hak kebendaan menjadikan kedudukan kreditor pemegang hak jaminan menjadi kreditor konkurren.

\section{DAFTAR PUSTAKA}

Agustina, S. (2015). Implementasi Asas Lex Specialis Derogat Lex Generali Dalam Sistem Peradilan Pidana. Masalah Masalah Hukum, 44(4).
Indonesia. Undang-Undang Nomor 13 Tahun 2003 tentang Ketenagakerjaan (2003).

Indonesia. Undang-Undang Nomor 37 Tahun 2004 tentang Kepailitan dan Penundaan Kewajiban Pembayaran Utang. (2004). Indonesia.

Mulyadi, K. (2001). Penyelesaian Utang Piutang Melalui Pailit atau Penundaan Kewajiban Pembayaran Utang. Bandung: Alumni.

Poesoko, H. dan I. D. A. S. (2016). Hukum Kepailitan: Kedudukan dan Hak Kreditor Separatis atas Benda Jaminan Debitor Pailit. Yogyakarta: LaksBang Justitia.

Sastrawidjaja, M. (2014). Hukum Kepailitan dan Penundaan Kewajiban Pembayaran Utang. Bandung: Alumni.

Sjahdeini, S. R. (2016). Sejarah, Asas dan Teori Hukum Kepailitan. Jakarta: Kencana.

Subhan, H. M. (2008). Hukum Kepailitan Prinsip, Norma, dan Praktik di Peradilan. Jakarta: Kencana.

Sularto. (2012). Perlindungan Hukum Kreditor Separatis Dalam Kepailitan. Mimbar Hukum, 24(2).

Sutedi, A. (2010). Hukum Hak Tanggungan. Jakarta: Sinar Grafika. 